\title{
An Experimental Study on Bond Strength of Reinforcing Steel in Self-Consolidating Concrete
}

\author{
Trevor J. Looney, Mahdi Arezoumandi*, Jeffery S. Volz, and John J. Myers
}

\author{
(Received June 27, 2012, Revised July 30, 2012, Accepted August 3, 2012, Published online September 18, 2012)
}

\begin{abstract}
An experimental investigation was conducted to compare the bond strength of reinforcing steel in self-consolidating concrete (SCC) with conventional concrete (CC). This study investigated two different compressive strengths of SCC as well as CC. The experimental program consisted of 24 pull-out specimens as well as 12 full-scale beams (three for each concrete type and strength). The pull-out specimens were based on RILEM recommendations, and the beam specimens were tested under a simply supported four-point loading condition. The CC test results served as a control and were used to evaluate the results from the SCC pull-out and beam specimen tests. Furthermore, a comparison was performed between results of this study and a bond database of $\mathrm{CC}$ specimens. These comparisons indicate that SCC beams possess comparable or slightly greater bond strength than CC beams.
\end{abstract}

Keywords: self-consolidating concrete, conventional concrete, bond strength, experimental study.

\section{Introduction}

Self-consolidating concrete (SCC) is a highly workable concrete that can spread under its own weight without segregation and bleeding. SCC was developed in Japan in the early 1980's by Okamura and colleagues at Tokyo University (Ozawa 1989). The motivation for this development was a lack of skilled workers for placing and consolidating concrete to make durable concrete structures (Daczko and Vachon 2006).

Like many new products, SCC was slow to gain popularity. It was used for the first time on a large scale for the Akashi-Kaikyo Bridge in Japan in 1998 (Okamura 1997). It began to spread in Asian and European countries before the United States. It gained acceptance in the United States around the year 2000 (Okamura 1997). SCC has become more popular because of several advantages. It reduces labor, equipment, job noise, and time of construction. It also facilitates the filling of densely reinforced sections and complex formworks (ACI Committee 237 2007).

There have been numerous studies conducted to determine the bond performance of SCC relative to conventional concrete (CC). Some researchers (Foroughi-Asl et al. 2008; Hassan et al. 2010) performed direct pull-out specimens while others (Turk et al. 2008; Castel et al. 2010) used beam specimens to study bond strength of SCC. Both groups concluded that no significant differences were observed between SCC

Department of Civil, Architectural and Environmental

Engineering, Missouri University of Science

and Technology, Rolla, MO 65409, USA.

*Corresponding Author; E-mail: ma526@mst.edu

Copyright ( $\odot$ The Author(s) 2012. This article is published

with open access at Springerlink.com and $\mathrm{CC}$ in terms of bond strength development. However, other studies (Dehn et al. 2000; Chan et al. 2003; Castel et al. 2006; Valcuende and Parra 2009) have shown that SCC has higher bond strength and less top-bar effect compared with CC. These discrepancies merit additional research.

There are three different approaches to developing an SCC mix design. The first is material-based, the second is chemicallybased, and the third is a hybrid of the first two. The first approach focuses on modifying the aggregate types and amounts. Typically, the coarse aggregate content is reduced and also rounder aggregate is used to improve the flowability of the SCC mix. The main disadvantage of this approach is that with a lower coarse aggregate content, the resulting concrete may suffer negative side effects such as reduced mechanical properties. To avoid this issue, the second approach was developed and, in this approach, the coarse aggregate and paste contents are kept the same as in a CC mix. To improve the flowability and stability of this type of mix, high-range water-reducing admixtures and viscosity-modifying admixtures are used. This current study used the third method - the hybrid approach to SCC mix design.

The following study presents the results of an experimental investigation that compares the bond strength of 24 pull-out and 12 full-scale SCC and CC beams. The results of this study were also compared with a bond database of CC beam specimens. The purpose of this study was to evaluate reinforcing bond in alternative SCC mix designs then those studied by previous researchers, as well as to add to the database of SCC bond test results in order to lead to changes or acceptance in design codes and standards.

\section{Experimental Program}

Several different methods are used to study bond between steel reinforcement and concrete. The four most common 


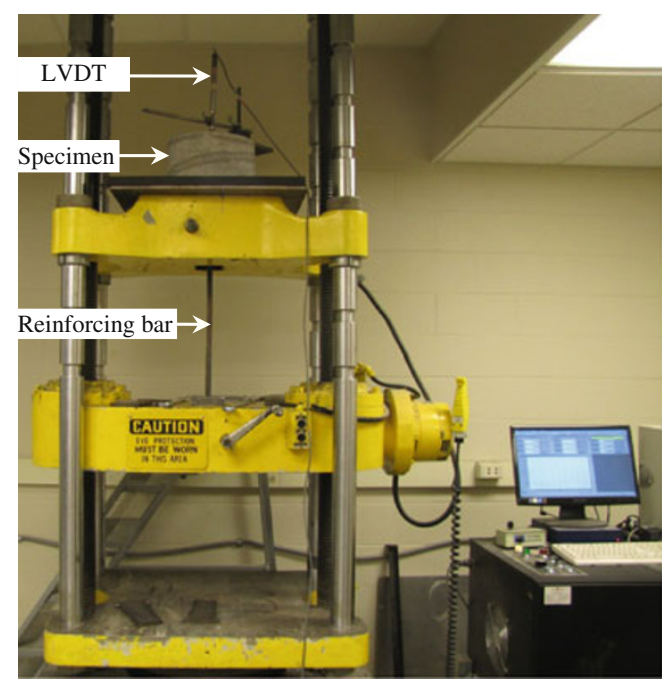

(a) Direct pull-out test setup

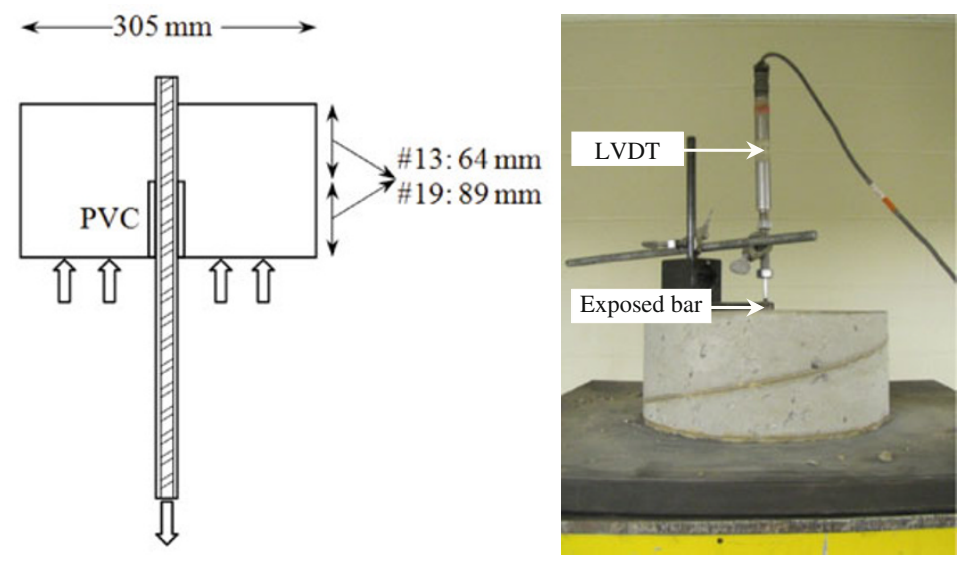

(b) Pull-out test specimen details

(c) LVDT installation to measure bar slip

Fig. 1 Pull-out test specimen.

methods are pull-out specimens, beam-end specimens, beam anchorage specimens, and beam splice specimens. The last three methods provide more realistic measures of bond strength compared with pull-out specimen tests. However, the pull-out specimen is more popular due to ease of construction and simplicity of the test. The main drawback with this test is that the stress state does not reflect the actual stress state within a reinforced concrete member. In the pull-out specimen test, the bar is in tension and the concrete surrounding the bar is in compression, but in most reinforced concrete members, both the bar and the surrounding concrete are in tension. For this reason, ACI 408-03 (ACI Committee 408 2003) does not recommend the pull-out specimen test to determine development length of reinforcement. However, pull-out specimen tests are valid in determining relative performance between different types of concretes or different types of reinforcing bar coatings (Al-Sulaimani et al. 1990; Carins and Abdullah 1994; Benmokrane et al. 1996; Tighiouart et al. 1998; Andrade et al. 2001; Belaid et al. 2001). The current study used both pull-out specimens and beam splice specimens to evaluate SCC reinforcement bond strength compared with CC.

\subsection{Specimen Design}

The following section contains details regarding the pullout and splice specimens used in the current study to evaluate bond between reinforcing steel and concrete.

\subsubsection{Pull-out Specimens}

The pull-out specimens were designed using RILEM 7-II128 (RILEM 1994) as a guide. The bars were embedded 10 times the bar diameter into the concrete specimen based on preliminary testing, with half of the length debonded using a section of polyvinyl chloride tubing. The RILEM report recommends casting the bars into concrete cubes that provide a clear cover of 4.5 times the bar diameter from the bar to the center of each side of the horizontal cross section. The specimens designed for this experiment exceeded the RILEM 7-II-128 requirement on clear cover and featured a $305 \mathrm{~mm}$ concrete cylinder to eliminate the potential for splitting and ensure that all of the specimens failed in the 


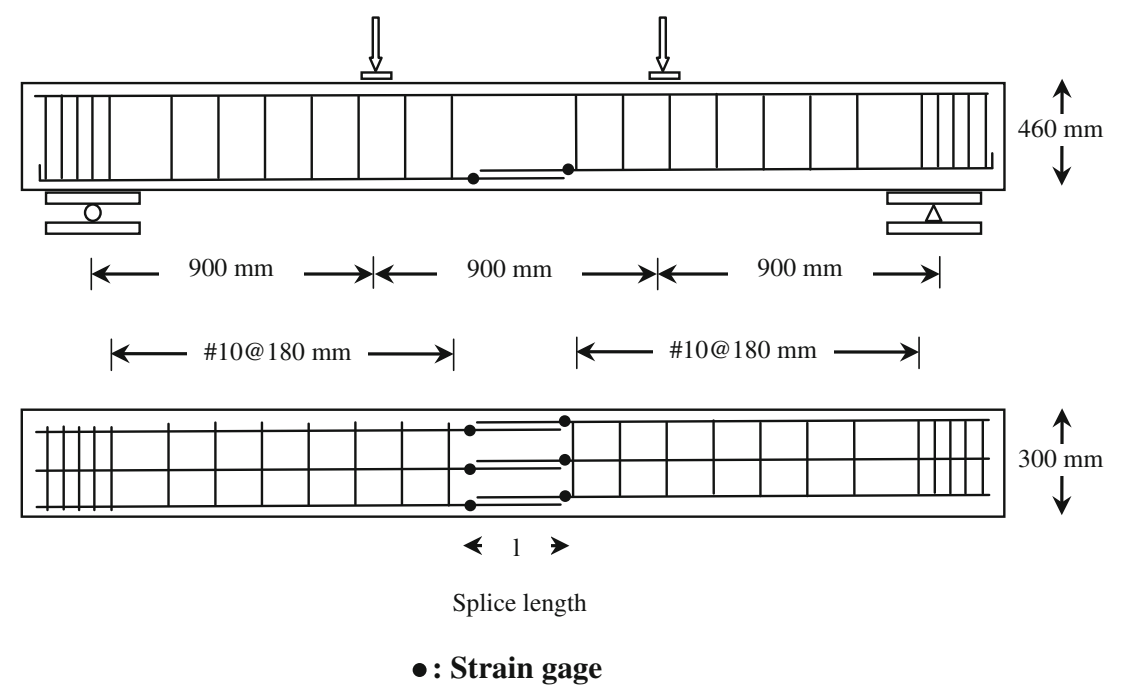

(a) Beam splice specimen reinforcing layout

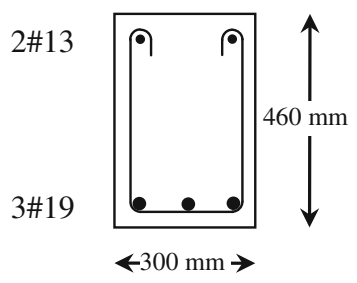

(b) Beam splice specimen cross section

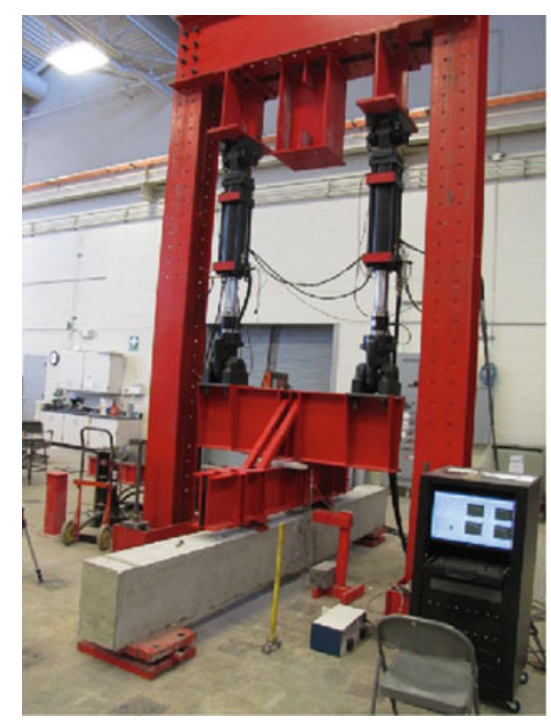

(c) Splice test setup with specimen loaded

Fig. 2 Load pattern, cross section, and location of strain gages on the beams.

same manner (pull-out). Figure 1 contains details of the pullout test specimens.

\subsubsection{Splice Specimens}

The splice specimens were designed using ACI 408 as a guide. Twelve beams (three for each concrete type and strength) were designed to preclude flexural and shear failures and satisfy the minimum and maximum longitudinal reinforcement requirements of ACI 318-08 (American Concrete Institute ACI Committee 2008). Figure 2 contains details of the splice test specimens. The beams measured $3,000 \mathrm{~mm}$ in length, with a cross section of $300 \times 460 \mathrm{~mm}^{2}$, and a splice in the longitudinal steel centered at midspan. The longitudinal steel consisted of three \#19 bars for the normal strength mixes and four \#19 bars for the high strength mixes, while the shear reinforcement consisted of \#10, U-shaped stirrups. One beam of each type was cast upside down to evaluate the top bar effect. The test setup used a simply supported four-point loading condition in order to place the splice under a uniform stress, as shown 
Table 1 Mechanical properties of reinforcing steel.

\begin{tabular}{c|c|c|c}
\hline Bar no. & Modulus of elasticity $(\mathrm{MPa})$ & Yielding strength $(\mathrm{MPa})$ & Elongation $(\mathrm{mm} / \mathrm{mm})$ \\
\hline \hline 13 & 196,600 & 485 & 0.0092 \\
\hline 19 & 206,250 & 580 & 0.0085 \\
\hline
\end{tabular}

Table 2 Mixture proportions of concrete.

\begin{tabular}{c|c|c|c|c|c|c|c}
\hline Mix & Water $\left(\mathrm{kg} / \mathrm{m}^{3}\right)$ & Cement $\left(\mathrm{kg} / \mathrm{m}^{3}\right)$ & Fly ash $\left(\mathrm{kg} / \mathrm{m}^{3}\right)$ & $\begin{array}{c}\text { Fine aggregate } \\
\left(\mathrm{kg} / \mathrm{m}^{3}\right)\end{array}$ & $\begin{array}{c}\text { Coarse aggregate } \\
\left(\mathrm{kg} / \mathrm{m}^{3}\right)\end{array}$ & AEA $\left(\mathrm{l} / \mathrm{m}^{3}\right)$ & HRWR $\left(1 / \mathrm{m}^{3}\right)$ \\
\hline \hline NCC & 165 & 445 & - & 691 & 955 & 0.33 & 1.04 \\
\hline NSCC & 165 & 445 & - & 856 & 790 & 0.33 & 1.38 \\
\hline HCC & 150 & 500 & 125 & 619 & 854 & 0.40 & 1.55 \\
\hline HSCC & 150 & 500 & 125 & 767 & 707 & 0.31 & 2.23 \\
\hline
\end{tabular}

Table 3 Fresh and hardened concrete properties.

\begin{tabular}{c|c|c|c|c}
\hline Property & NCC & NSCC & HCC & HSCC \\
\hline \hline Slump (mm) & 203 & - & 51 & 597 \\
\hline Slump flow (mm) & - & 610 & - & 546 \\
\hline J-Ring (mm) & - & 527 & 2.5 & 3 \\
\hline Air content (\%) & 6 & 6 & 3.9 & 2400 \\
\hline Unit weight $\left(\mathrm{kg} / \mathrm{m}^{3}\right)$ & 2240 & 3.6 & 4.8 & 3.9 \\
\hline $\begin{array}{c}\text { Split cylinder strength } \\
(\mathrm{MPa})^{\mathrm{a}}\end{array}$ & 3.0 & 3.4 & 66.4 & 3.7 \\
\hline $\begin{array}{c}\text { Flexural strength (MPa) } \\
\text { Compressive strength } \\
(\mathrm{MPa})^{\mathrm{a}}\end{array}$ & 3.4 & 47.2 & & 67.2 \\
\hline
\end{tabular}

${ }^{a}$ Values represent the average of three cylinders (ASTM C39-12 and C496-11).

b Values represent the average of three beams (ASTM C78-10).

in Fig. 2, with the stirrups discontinued within the center portion of the beam to provide an unconfined splice condition. To ensure a bond failure prior to a flexural failure, the splice length was chosen as $70 \%$ of the development length calculated in accordance with Eq. 12-1 in ACI 318-08, repeated as Eq. 1.

$$
1_{d}=\frac{3}{40} \frac{f_{y}}{\sqrt{f_{c}^{\prime}}} \frac{\psi_{t} \psi_{e} \psi_{s}}{\left(\frac{c_{b}+k_{\text {tr }}}{d_{b}}\right)} d_{b}
$$

where $l_{d}$ the development length, $f_{y}$ the specified yield strength of reinforcement, $\lambda$ the lightweight concrete modification factor, $\mathrm{f}_{\mathrm{c}}^{\prime}$ the specified compressive strength of concrete, $\Psi_{t}$ the reinforcement location modification factor, $\Psi_{\mathrm{e}}$ the reinforcement coating modification factor, $\Psi_{\mathrm{s}}$ the reinforcement size modification factor, $c_{b}$ the smaller of the distance from center of a bar to nearest concrete surface and one-half the center-to-center spacing of bars being developed, $\mathrm{K}_{\text {tr }}$ the transverse reinforcement index, $\mathrm{d}_{\mathrm{b}}$ the nominal diameter of the reinforcing bar.
Based on these calculations, the splice lengths for the normal and high strength mixes were 300 and $360 \mathrm{~mm}$, respectively.

\subsection{Materials}

The concrete was supplied by a local ready-mix supplier (Rolla, MO). The mixtures used ASTM Type I Portland cement and, for the high strength mixes, ASTM Class C fly ash from the Ameren Labadie Power Plant (Labadie, MO). The coarse aggregate consisted of crushed limestone with a maximum nominal aggregate size of $19 \mathrm{~mm}$ from Jefferson City Dolomite (Jefferson City, MO). The fine aggregate was natural sand from Missouri River Sand (Jefferson City, MO).

All of the reinforcing bars were from the same heat of steel, used the same deformation pattern, and met the requirements of ASTM A615-09 (ASTM A615 2009) Grade 60, $414 \mathrm{MPa}$ material. Table 1 contains the tested mechanical properties of the reinforcing steel. The rib height, rib spacing, and relative rib area for each bar size was in accordance with ACI 408R-03 and ASTM A615-09, with the \#13 and \#19 reinforcing bars used in the pull-out and 
Table 4 Pull-out test results.

\begin{tabular}{|c|c|c|c|c|c|c|c|c|c|}
\hline Section & $\mathrm{f}_{\mathrm{c}}^{\prime}(\mathrm{MPa})$ & $\mathrm{P}(\mathrm{kN})$ & $\mu(\mathrm{MPa})^{\mathrm{a}}$ & 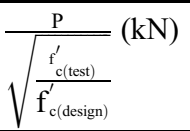 & $P_{\text {ave }}(\mathrm{kN})$ & $\operatorname{COV}(\%)^{b}$ & $\frac{\mathrm{P}}{\sqrt[4]{\frac{\mathrm{f}^{\prime}(\text { test })}{\mathrm{f}_{\mathrm{c}(\text { design })}^{\prime}}}}(\mathrm{kN})$ & $\mathrm{P}_{\mathrm{ave}}(\mathrm{kN})$ & $\operatorname{COV}(\%)^{b}$ \\
\hline \multicolumn{10}{|l|}{$\mathrm{NCC}$} \\
\hline $13-1$ & \multirow[t]{6}{*}{39.9} & 55.2 & 21.0 & 56.5 & \multirow[t]{3}{*}{55.6} & \multirow[t]{3}{*}{3.5} & 55.7 & \multirow[t]{3}{*}{54.7} & \multirow[t]{3}{*}{3.5} \\
\hline $13-2$ & & 55.5 & 21.2 & 56.9 & & & 56.0 & & \\
\hline $13-3$ & & 52.0 & 19.8 & 53.3 & & & 52.5 & & \\
\hline $19-1$ & & 134.4 & 25.2 & 137.6 & \multirow[t]{3}{*}{136.1} & \multirow[t]{3}{*}{1.1} & 135.6 & \multirow[t]{3}{*}{134.1} & \multirow[t]{3}{*}{1.1} \\
\hline $19-2$ & & 132.9 & 24.9 & 136.1 & & & 134.1 & & \\
\hline $19-3$ & & 131.4 & 24.6 & 134.6 & & & 132.6 & & \\
\hline \multicolumn{10}{|l|}{ NSCC } \\
\hline $13-1$ & \multirow[t]{6}{*}{47.2} & 69.0 & 26.3 & 64.6 & \multirow[t]{3}{*}{63.8} & \multirow[t]{3}{*}{1.8} & 66.8 & \multirow[t]{3}{*}{66.0} & \multirow[t]{3}{*}{1.9} \\
\hline $13-2$ & & 66.7 & 25.4 & 62.5 & & & 64.5 & & \\
\hline $13-3$ & & 68.8 & 26.2 & 64.4 & & & 66.6 & & \\
\hline $19-1$ & & 161.9 & 30.3 & 151.6 & \multirow[t]{3}{*}{151.1} & \multirow[t]{3}{*}{2.9} & 156.7 & \multirow[t]{3}{*}{156.1} & \multirow[t]{3}{*}{2.9} \\
\hline $19-2$ & & 156.5 & 29.3 & 146.6 & & & 151.4 & & \\
\hline $19-3$ & & 165.7 & 31.0 & 155.2 & & & 160.3 & & \\
\hline \multicolumn{10}{|l|}{$\mathrm{HCC}$} \\
\hline $13-1$ & \multirow[t]{6}{*}{66.4} & 83.0 & 31.6 & 84.6 & \multirow[t]{3}{*}{86.4} & \multirow[t]{3}{*}{5.2} & 73.7 & \multirow[t]{3}{*}{75.3} & \multirow[t]{3}{*}{5.2} \\
\hline $13-2$ & & 81.6 & 31.1 & 83.1 & & & 72.5 & & \\
\hline $13-3$ & & 89.8 & 34.2 & 91.5 & & & 79.8 & & \\
\hline $19-1$ & & 194.2 & 36.4 & 197.9 & \multirow[t]{3}{*}{199.4} & \multirow[t]{3}{*}{0.75} & 172.5 & \multirow[t]{3}{*}{173.9} & \multirow[t]{3}{*}{0.75} \\
\hline $19-2$ & & 197.1 & 36.9 & 200.9 & & & 175.1 & & \\
\hline $19-3$ & & 195.8 & 36.7 & 199.5 & & & 174.0 & & \\
\hline HSCC & & & & & & & & & \\
\hline $13-1$ & 67.2 & 79.4 & 30.3 & 80.4 & 81.4 & 1.4 & 70.3 & 71.2 & 1.3 \\
\hline $13-2$ & & 80.4 & 30.6 & 81.4 & & & 71.2 & & \\
\hline $13-3$ & & 81.5 & 31.1 & 82.6 & & & 72.2 & & \\
\hline $19-1$ & & 182.8 & 34.2 & 185.2 & 182.2 & 1.6 & 161.9 & 159.3 & 1.6 \\
\hline $19-2$ & & 179.7 & 33.7 & 182.0 & & & 159.2 & & \\
\hline $19-3$ & & 177.1 & 33.2 & 179.4 & & & 156.9 & & \\
\hline
\end{tabular}

${ }^{a}$ Average bond strength.

${ }^{\mathrm{b}}$ Coefficient of variation (COV).

splice specimens having relative rib areas of 0.088 and 0.081 , respectively.

\subsection{Mixture Proportions}

The mixture proportions are given in Table 2. The normal strength concrete mixes had a target compressive strength of $41 \mathrm{MPa}$ and are designated NCC and NSCC for the CC and SCC, respectively. The high strength concrete mixes had a target compressive strength of $69 \mathrm{MPa}$ and are designated HCC and HSCC for the CC and SCC, respectively.

\subsection{Fabrication and Curing of Test Specimens}

Both the pull-out and beam splice specimens were constructed and tested in the Structural Engineering High-Bay Research Laboratory (SERL) at Missouri University of Science and Technology. After casting, the specimens and the quality control/quality assurance companion cylinders (ASTM C39-12 (ASTM C39 2012) and C496-11 (ASTM C496 2011)) and beams (ASTM C78-10 (ASTM C78 2010)) were covered with both wet burlap and a plastic sheet. All of the specimens and companion cylinders and beams were 


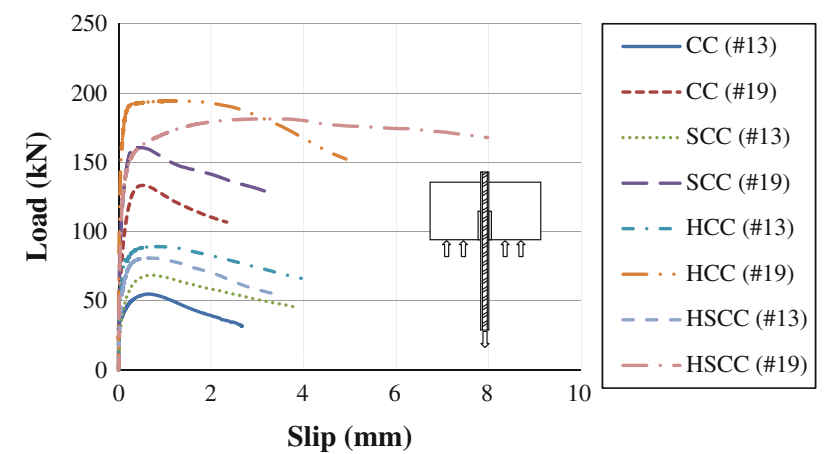

(a) Pull-out test

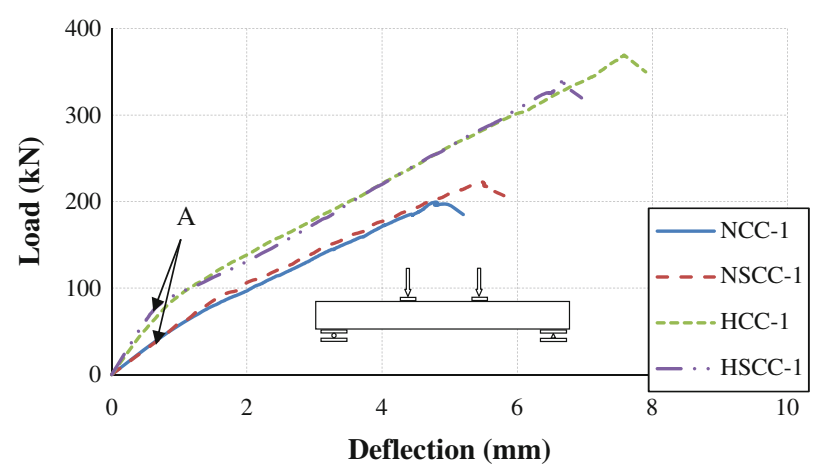

(b) Splice specimen test

Fig. 3 Load-deflections of the specimens.

moist cured for 3 days and, after formwork removal, were stored in the laboratory until they were tested.

\subsection{Fresh and Hardened Properties}

Table 3 presents the fresh and hardened strength properties of the $\mathrm{CC}$ and SCC mixes.

\section{Test Setup and Procedure}

The following section contains details regarding the test setup for the pull-out and beam splice specimen testing.

\subsection{Pull-out Test}

As shown in Fig. 1, the pull-out specimens were loaded into an $890-\mathrm{kN}$ Tinius Olson machine by rotating the specimen $180^{\circ}$, bar side down, and threading the bar through a thin piece of rubber and the head of the machine until the specimen rested evenly on the rubber. The free end of the bar was clamped into a lower component of the Tinius Olson machine. A magnetic arm holding a linear variable differential transformer (LVDT) was then placed on top of the specimen. The LVDT was placed directly on top of the exposed rebar on the back end of the specimen to record bar slip.

The loading rate for the Tinius Olson machine was set at $2.5 \mathrm{~mm} / \mathrm{min}$. to avoid any dynamic effect and in order to insure a sufficient number of data points prior to failure. The load was recorded on a data acquisition computer linked to the test machine. The LVDT was also monitored to record bar slip as a function of load. The test protocol consisted of loading the bar in tension to the maximum capacity and then continuing to apply load in order to develop the full load-slip curve.

\subsection{Splice Specimen Test}

As shown in Fig. 2, a load frame was assembled and equipped with two 490-kN, servo-hydraulic actuators intended to apply the two point loads to the beams. The load was applied in a displacement control method at a rate of $0.50 \mathrm{~mm} / \mathrm{min}$. The beams were supported on a roller and a pin support, $150 \mathrm{~mm}$ from each end of the beam, creating a four-point loading condition with the two actuators. An LVDT was used to measure the deflection at the beam center and strain gages were installed at both ends of each splice to monitor the strain in the longitudinal reinforcement during the test. Figure 2 shows both the beam loading pattern and the location of the strain gages. During the test, any cracks that formed on the surface of the beam were marked at load increments of approximately $22 \mathrm{kN}$, and both the deformation and strains were monitored until the beam reached failure.

\section{Test Results and Discussions}

The following section contains the results from the pullout and splice specimen tests as well as a discussion and comparison between $\mathrm{CC}$ and SCC.

\subsection{Pull-out Tests}

All of the pull-out specimens experienced a bond shear failure except for one of the \#19 bar HSCC specimens where the reinforcement yielded prior to a bond failure. A bond shear failure occurs when the reinforcing bar and associated concrete located between the transverse ribs pulls out of the specimen as a cylinder without splitting the remaining concrete. Table 4 indicates the results of the pull-out tests. To compare the test results of the SCC and the $\mathrm{CC}$, the values must be adjusted to reflect the different compressive strengths of the specimens. In the majority of design standards, bond strength is a function of the inverse square root of the compressive strength of the concrete (e.g., ACI 318-08, AASHTO LRFD-07 (American Association of State and Highway Transportation Officials (AASHTO) 2007), AS 3600-09 (AS 2009),CSA-04 (CSA 2004), and JSCE-07 (Japan Society of Civil Engineers 2007)), but ACI 408R-03 recommends a relationship based on the inverse fourth root of the compressive strength of the concrete.

Consequently, to compare the bond strength of the SCC and $\mathrm{CC}$ specimens, the test results were normalized with both the square root and fourth root of the compressive strength of the concrete. As shown in Table 4, the bond strengths of the \#13 and \#19 bars for the NSCC were 16 and $12 \%$ higher than the NCC when normalized by the square root of compressive strength and 21 and $16 \%$ higher when normalized by the fourth root of compressive strength, respectively. In contrast, the bond strength of the \#13 and \#19 bars for the HSCC decreased by 6 and $9 \%$ compared with the HCC when normalized by the square root of compressive strength of concrete and decreased by 5 and $8 \%$ when normalized by the fourth root of compressive strength, respectively. 


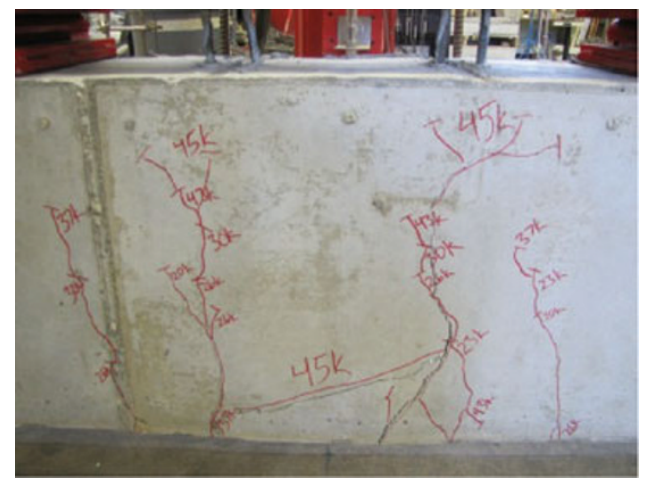

(a) $\mathrm{NCC}$

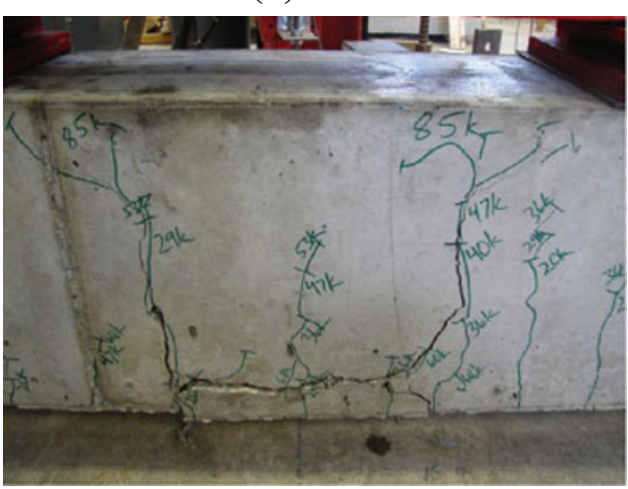

(c) $\mathrm{HCC}$

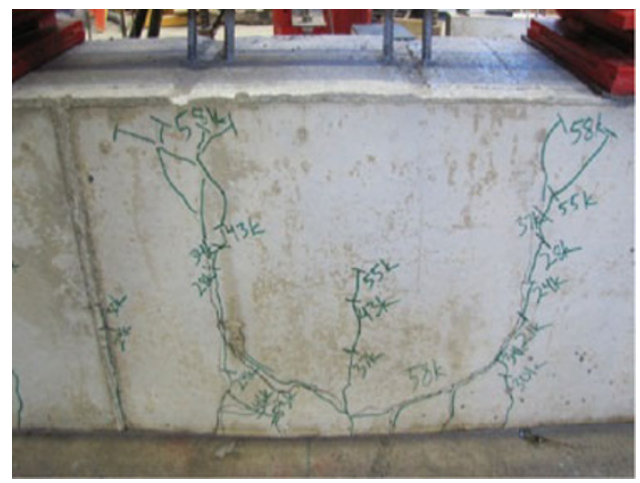

(b) NSCC

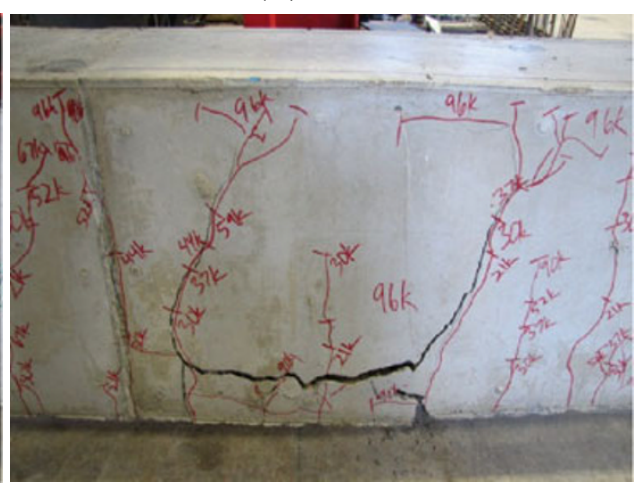

(d) $\mathrm{HSCC}$

Fig. 4 Crack pattern of the beams at bond failure.

Table 5 Longitudinal reinforcement stress (MPa).

\begin{tabular}{|c|c|c|c|c|c|c|c|c|c|}
\hline \multirow[t]{2}{*}{ Section } & \multirow[t]{2}{*}{$f_{c}^{\prime}$} & \multicolumn{2}{|c|}{ Measured $^{\mathrm{a}}$} & \multicolumn{4}{|c|}{ Moment-curvature method } & \multicolumn{2}{|c|}{ Measured $^{\mathrm{a}}$} \\
\hline & & Measured $^{\mathrm{a}}$ & Ave. & $(\mathrm{M}-\Phi)^{\mathrm{b}}$ & Ave. & $(\mathrm{M}-\Phi)^{\mathrm{c}}$ & Ave. & $\frac{\mathrm{f}_{s}}{\sqrt{\frac{\mathrm{f}_{\mathrm{c}(\text { test })}^{\prime}}{\mathrm{f}_{\mathrm{c} \text { (design) }}^{\prime}}}}$ & $\frac{\mathrm{f}_{\mathrm{s}}}{\sqrt[4]{\frac{\mathrm{f}_{\mathrm{c}(\mathrm{test})}^{\prime}}{\mathrm{f}_{\mathrm{c}(\text { design })}}}}$ \\
\hline \multicolumn{10}{|l|}{ NCC } \\
\hline 1 & \multirow[t]{3}{*}{39.9} & 341 & \multirow[t]{2}{*}{345} & 239 & \multirow[t]{2}{*}{284} & 324 & \multirow[t]{2}{*}{347} & \multirow[t]{2}{*}{353} & \multirow[t]{2}{*}{349} \\
\hline 2 & & 350 & & 328 & & 370 & & & \\
\hline Top & & 377 & 377 & 238 & 238 & 321 & 321 & 386 & 382 \\
\hline \multicolumn{10}{|l|}{ NSCC } \\
\hline 1 & \multirow[t]{3}{*}{47.2} & 436 & \multirow[t]{2}{*}{424} & 319 & \multirow[t]{2}{*}{310} & 403 & \multirow[t]{2}{*}{396} & \multirow[t]{2}{*}{397} & \multirow[t]{2}{*}{410} \\
\hline 2 & & 412 & & 301 & & 388 & & & \\
\hline Top & & 349 & 349 & 271 & 271 & 360 & 360 & 327 & 338 \\
\hline \multicolumn{10}{|l|}{$\mathrm{HCC}$} \\
\hline 1 & \multirow[t]{3}{*}{66.4} & 427 & \multirow[t]{2}{*}{413} & 499 & \multirow[t]{2}{*}{458} & 554 & \multirow[t]{2}{*}{527} & \multirow[t]{2}{*}{421} & \multirow[t]{2}{*}{417} \\
\hline 2 & & 399 & & 416 & & 500 & & & \\
\hline Top & & 509 & 509 & 552 & 552 & 567 & 567 & 519 & 514 \\
\hline \multicolumn{10}{|l|}{ HSCC } \\
\hline 1 & \multirow[t]{3}{*}{67.2} & 379 & \multirow[t]{2}{*}{416} & 429 & \multirow[t]{2}{*}{454} & 510 & \multirow[t]{2}{*}{526} & \multirow[t]{2}{*}{421} & \multirow[t]{2}{*}{419} \\
\hline 2 & & 452 & & 479 & & 541 & & & \\
\hline Top & & 546 & 546 & 562 & 562 & 624 & 624 & 553 & 549 \\
\hline
\end{tabular}

\footnotetext{
a Strain (from strain gages) multiplied by modulus of elasticity.
}

b Popovic, Thorenfeldt, and Collins stress-strain model.

${ }^{c}$ Hognestad stress-strain model (ACI 408R-03 recommended method). 
Table 6 Experimental-to-theoretical ratio of longitudinal reinforcement stress.

\begin{tabular}{|c|c|c|}
\hline Section & $\left(\frac{f_{\text {s(test) }}}{f_{s(M-\phi)}}\right)_{\text {ave }}^{\mathrm{a}}$ & $\left(\frac{f_{\text {s(test })}}{f_{s(M-\phi)}}\right)_{a v e}^{b}$ \\
\hline \multicolumn{3}{|l|}{ NCC } \\
\hline 1 & \multirow[t]{2}{*}{1.21} & \multirow[t]{2}{*}{0.99} \\
\hline 2 & & \\
\hline Top & 1.58 & 1.17 \\
\hline \multicolumn{3}{|l|}{ NSCC } \\
\hline 1 & \multirow[t]{2}{*}{1.37} & \multirow[t]{2}{*}{1.07} \\
\hline 2 & & \\
\hline Top & 1.29 & 0.97 \\
\hline Ave. & 1.36 & 1.05 \\
\hline $\operatorname{COV}(\%)$ & 11.7 & 8.7 \\
\hline \multicolumn{3}{|l|}{$\mathrm{HCC}$} \\
\hline 1 & \multirow[t]{2}{*}{0.90} & \multirow[t]{2}{*}{0.78} \\
\hline 2 & & \\
\hline Top & 0.92 & 0.90 \\
\hline \multicolumn{3}{|l|}{ HSCC } \\
\hline 1 & \multirow[t]{2}{*}{0.92} & \multirow[t]{2}{*}{0.80} \\
\hline 2 & & \\
\hline Top & 0.97 & 0.88 \\
\hline Ave. & 0.93 & 0.84 \\
\hline $\operatorname{COV}(\%)$ & 3.2 & 7.0 \\
\hline
\end{tabular}

\footnotetext{
a Popovic, Thorenfeldt, and Collins stress-strain curve.

${ }^{\mathrm{b}}$ Hognested stress-strain curve (ACI 408R-03 recommended method).
}

Also, as shown in Fig. 3a, no significant difference was observed between the average load-slip behavior of the NCC and NSCC and also the HCC and HSCC pull-out specimens. As mentioned earlier, the only difference was that one of the \#19 bar HSCC specimens yielded prior to a bond shear failure.

\subsection{Splice Specimen Tests}

All of the beams failed in bond, experiencing a splitting failure. Based upon data collected from the strain gages, none of the longitudinal reinforcement reached yield at failure. Figure $3 \mathrm{~b}$ shows the load-deflection behavior for one of the beam specimens of each concrete type (the deflection was measured at midspan). Before the first flexural cracks occurred (point A), all of the beams displayed a steep linear elastic behavior. After the appearance of flexural cracks in the maximum moment region, by increasing the load, new flexural cracks were formed between the two point loads. Upon further increasing the applied load, a bond failure occurred. As Fig. $3 \mathrm{~b}$ reveals, the load-deflection behavior of the NSCC and NCC and also HSCC and HCC beams were essentially identical except for the cracking moment (point A) and value at failure. Similarly, the cracking patterns experienced by the NSCC and NCC and also HSCC and HCC were essentially identical, as shown in Fig. 4. All of the beams displayed a horizontal splitting failure along the length of the longitudinal splice.

Table 5 summarizes the longitudinal reinforcement stress at bond failure as determined from the strain gages, where the specimen designation "Top" refers to the specimen cast upside down to evaluate the top bar effect. Also included in Table 5 are calculated steel stresses based on the momentcurvature approach recommended in ACI 408, with the first calculated value based on the Popovic, Thorenfeldt, and Collins stress-strain model, and the second calculated value based on the Hognestad stress-strain model (ACI 408R-03 recommended method). Furthermore, as with the pull-out test, to compare the bond strength of the NSCC and NCC and also HSCC and HCC specimens, the test results were normalized with both the square root and fourth root of the compressive strength of the concrete.

Test results show that the NSCC beams had 12 and $17 \%$ higher average longitudinal reinforcement stress compared with the NCC beams when normalized by the square root and fourth root of the compressive strength of the concrete for the bottom bars, respectively. In contrast, for the top reinforcement, the NSCC beams had 15 and $12 \%$ lower average longitudinal reinforcement stress compared with the 


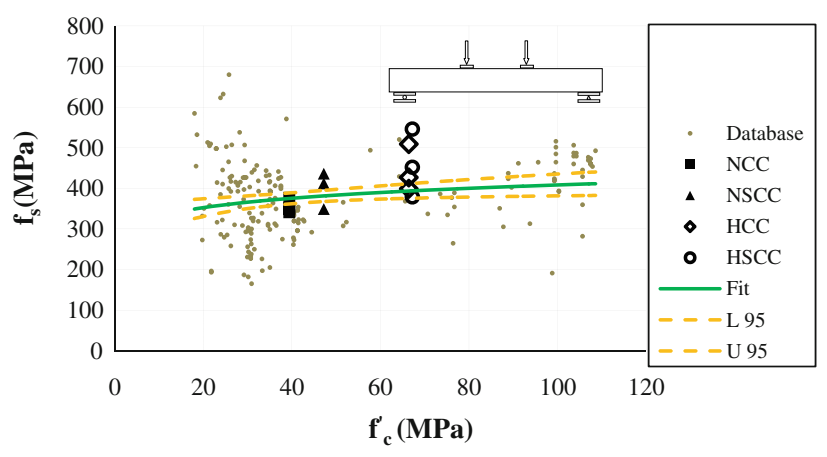

Fig. 5 Longitudinal steel reinforcement stress versus compressive strength of concrete (database of $\mathrm{ACl} 408-03$ and test results of this study).

NCC beams when normalized by the square root and fourth root of the compressive strength of the concrete, respectively. The HSCC and HCC beams had the same average longitudinal reinforcement stress in the bottom bars when normalized with both the square and fourth root of the concrete compressive strength. For the top bars, the average longitudinal reinforcement stress for the HSCC beams increased by $7 \%$ compared with the HCC beams when normalized with both the square and fourth root of the concrete compressive strength.

Contrary to previous research results for $\mathrm{CC}$, a top bar effect didn't occur for the specimens studied, both $\mathrm{CC}$ and SCC. In fact, for all specimens except the NSCC specimens, the top bars had higher bond strength than the bottom bars, which may have been due to the very low $\mathrm{w} / \mathrm{c}$ ratios $(0.37$ and 0.24 for the normal and high strength mixes, respectively) and the use of fly ash in the high strength mixes. In addition, the beams were not overly deep and were only slightly above the cutoff for when to consider top bar effects. These factors may have resulted in a decrease in the amount of bleed water accumulating beneath the top bars, which is the primary cause of the top bar effect. Some previous studies have also found a decrease in the top bar effect for SCC (Dehn et al. 2000; Chan et al. 2003; Castel et al. 2006; Valcuende and Parra 2009), while others have not (Turk et al. 2008; Castel et al. 2010). Due to the limited number of top bar specimens used in this study - one for each concrete type-further research is needed to reach a definitive conclusion.

Table 6 presents the ratio of experimental-to-theoretical stress in the longitudinal reinforcement, with the theoretical values based on the moment-curvature analysis recommended in ACI 408 (ACI Committee 408 2003). The table includes analysis results based on two different stress-strain models - the Hognestad model recommended in ACI 408 and the Popovic, Thorenfeldt, and Collins model. The authors investigated both models to determine whether any noticeable differences resulted based on the assumed stress-strain diagram. The measured stresses are based on the strain gages installed at the start of each splice (see Fig. 2). Even with the potential for slight inaccuracies in the strain gage readings due to localized cracking and the slight reduction in cross section required for mounting the gages, the measured readings offer a valuable basis of comparison with the moment-curvature results. Based on the strain gage measurements, both stressstrain curve methods underestimated the longitudinal reinforcement stress of the NCC and NSCC beams, but overestimated the longitudinal reinforcement stress for the HCC and HSCC beams. The Popovic, Thorenfeldt, and Collins stressstrain model predicts the longitudinal reinforcement stress of the NCC and NSCC beams better than the Hognestad stressstrain model. In contrast, the bar stress calculated based on the Hognestad stress-strain model had better agreement with the $\mathrm{HCC}$ and HSCC beam results.

\subsection{Comparison of Test Results with Bond Test Database}

Figure 5 presents the longitudinal steel reinforcement stress versus compressive strength of concrete for this study as well as the wealth of bond test data available in the literature (ACI 408-03). Given the significant scatter of the database of previous bond test results, it is somewhat difficult to draw definitive conclusions on the current test values. Nonetheless, visually, Fig. 5 seems to indicate that the $\mathrm{CC}$ and SCC test results follow the same general trend of increasing bond strength as a function of the compressive strength of the concrete. Furthermore, statistical analysis of the data indicates that one of the beams of both the NCC and NSCC test results falls below a $95 \%$ confidence interval of a nonlinear regression curve fit of the database. The HCC and HSCC and the other two NCC and NSCC test results fall within and above a $95 \%$ confidence interval of the nonlinear regression curve fit. As a result, it would appear that the bond strength of SCC for the beams tested in this study is comparable or greater than $\mathrm{CC}$.

\section{Findings and Conclusions}

The purpose of this study was to evaluate reinforcing bond in alternative SCC mix designs then those studied by previous researchers, as well as to add to the database of SCC bond test results in order to lead to changes or acceptance in design codes and standards. To study the bond strength of reinforcing steel in SCC, 24 pull-out specimens as well as 12 full-scale beams (both $\mathrm{CC}$ and SCC) were constructed and tested to failure.

Based on the results of this study, the following findings and conclusions are presented for the pull-out tests:

- Bond strength of the NSCC was higher than the NCC by approximately $15 \%$.

- Bond strength of the HCC was higher than the HSCC by approximately $7 \%$.

- No significant difference was observed in the load-slip behavior between the NSCC and NCC and also the HSCC and HCC specimens.

The following findings and conclusions are presented for the splice tests:

- The average longitudinal reinforcement steel stress of the NSCC was approximately $15 \%$ higher than the NCC. 
- The average longitudinal reinforcement steel stress of the HSCC was virtually identical with the HCC.

- The load-deflection behavior of the NSCC and NCC and also the HSCC and HCC beams was essentially identical except for the cracking moment and value at failure.

- Based on the strain gage measurements, the moment curvature method based on the Popovic, Thorenfeldt, and Collins stress-strain model more accurately predicted the longitudinal reinforcement stress of the NCC and NSCC beams compared with the Hognestad stress-strain model.

- Based on the strain gage measurements, the Hognestad stress-strain model had better agreement with the HCC and HSCC beam results compared with the Popovic, Thorenfeldt, and Collins stress-strain model.

- Based on a comparison of the specimens studied in this investigation with a bond database of CC beam specimens, it appears that NSCC and HSCC possess reinforcement bond strength comparable or slightly greater than $\mathrm{NCC}$ and $\mathrm{HCC}$, respectively.

However, due to the limited nature of the data set regarding aspect ratio, mix designs, aggregate type and content, etc., investigated, the researchers recommend further testing to increase the database of SCC bond test results.

\section{Acknowledgments}

The authors gratefully acknowledge the financial support provided by the Missouri Department of Transportation (MoDOT) and the National University Transportation Center at Missouri University of Science and Technology. The authors would also like to thank the support staff in the Department of Civil, Architectural and Environmental Engineering and Center for Infrastructure Engineering Studies at Missouri S\&T for their efforts. The authors are also grateful for the ideas and help of Dr. David Darwin, the Deane E. Ackers Distinguished Professor of Civil Engineering, University of Kansas. The conclusions and opinions expressed in this paper are those of the authors and do not necessarily reflect the official views or policies of the funding institutions.

\section{Open Access}

This article is distributed under the terms of the Creative Commons Attribution License which permits any use, distribution, and reproduction in any medium, provided the original author(s) and the source are credited.

\section{References}

ACI Committee 237. (2007). Self-consolidaing concrete (ACI 237R-07). Farmington Hills, MI: American Concrete Institute.
ACI Committee 408. (2003). Bond and Development of Straight Reinforcing Bars in Tension (ACI 408R-03). Farmington Hills, MI: American Concrete Institute.

Al-Sulaimani, G. J., Kaleemullah, M., Basunbul, I. A., \& Rasheeduzzafar. (1990). Influence of corrosion and cracking on bond behavior and strength of reinforced concrete members. ACI Structural Journal, 87(2), 220-231.

American Association of State and Highway Transportation Officials (AASHTO). (2007). AASHTO LRFD Bridge Design Specifications (4th ed., pp. 72-84). Washington DC: AASHTO.

American Concrete Institute ACI Committee. (2008). Building code requirements for structural concrete ACI 318-08 and commentary 318R-08. ACI 318-08/318R-08 (pp. 155-168). Farmington Hills, MI: American Concrete Institute.

Andrade, C., Arteaga, A., Lopez-Hombrados, C., \& Vazquez, A. (2001). Tests on bonds of galvanized rebar and concrete cured in seawater. Journal of Materials in Civil Engineering, 13(5), 319-324.

AS 3600. (2009). Concrete structures (pp. 105-109). Sydney: Standards Australia.

ASTM A615/A615M. (2009). Standard specification for deformed and plain carbon-steel bars for concrete reinforcement. West Conshohocken, PA: ASTM.

ASTM C 78/C 78M. (2010). Standard test method for flexural strength of concrete (using simple beam with third-point loading. West Conshohocken, PA: ASTM.

ASTM C 496/C 496M. (2011). Standard test method for splitting tensile strength of cylindrical concrete. West Conshohocken, PA: ASTM.

ASTM C 39/C 39M. (2012). Standard test method for compressive strength of cylindrical concrete specimens. West Conshohocken, PA: ASTM.

Belaid, F., Arlique, G., \& Francois, R. (2001). Effect of bar properties on bond strength of galvanized reinforcement. Journal of Materials in Civil Engineering, 13(6), 454-458.

Benmokrane, B., Challal, O., \& Masmoudi, R. (1996). Flexural response of concrete beams reinforced with FRP reinforcing bars. ACI Structural Journal, 91(2), 46-55.

Carins, J., \& Abdullah, R. (1994). Fundamental tests on the effects of an epoxy coating on bond strength. ACI Materials Journal, 91(4), 331-338.

Castel, A., Thierry, V., Kriengkai, V., \& Raoul, F. (2006). Effect of reinforcing bar orientation and location on bond with self-consolidating concrete. ACI Structural Journal, 103, S103-S159.

Castel, A., Vidal, T., \& Francois, R. (2010). Bond and cracking properties of self-consolidating concrete. Journal of Construction and Building Materials, 24(7), 1222-1231.

Chan, Y., Chen, Y., \& Liu, Y. (2003). Development of bond strength of reinforcement steel in self-consolidating concrete. ACI Structural Journal, 100, S100-S152.

CSA CAN3-A23.3. (2004). Design of concrete standards for buildings (pp. 53-61). Ontario: Rexdale.

Daczko, J., \& Vachon, M. (2006). "Self consolidating concrete (SCC)”, significance of tests and properties of concrete and concrete-making materials STP $169 D$ (pp. 637-645). West Conshohocken: ASTM International. 
Dehn, F., Holschemacher, K., \& Weibe, D. (2000). Self-compacting concrete (SCC) time development of the material properties and the bond behavior. Universität Leipzig. Retrieved July 2012, from http://www.wilbertprecast.com/ documents/scc.pdf.

Foroughi-Asl, A., Dilmaghani, S., \& Famili, H. (2008). Bond strength of reinforcement steel in self-compacting concrete. International Journal of Civil Engineering, 6(1), 24-33.

Hassan, A., Hossain, K., \& Lachemi, M. (2010). Bond strength of deformed bars in large reinforced concrete members cast with industrial self-consolidating concrete mixture. Journal of Construction and Building Materials, 24(4), 520-530.

Japan Society of Civil Engineers. (2007). Standard specification for concrete structure (pp. 154-159), JSCE No. 15. Tokyo: JSCE (in Japanese).

Okamura, H. (1997). Self-compacting high-performance concrete. Concrete International, 19, 50-54.

Ozawa, K., Maekawa, K., Kunishima, M., \& Okamura, H. (1989). Development of high performance concrete based on the durability design of concrete structures. In Proceedings of the second East-Asia and pacific conference on structural engineering and construction (EASEC-2), Chiang Mai (Vol. 1, pp. 445-450).

RILEM 7-II-128. (1994). RC6: bond test for reinforcing steel. 1. Pull-Out Test. RILEM technical recommendations for the testing and use of construction materials (pp. 102-105). London: E \& FN Spon.

Tighiouart, B., Benmokrane, B., \& Gao, D. (1998). Investigation of bond in concrete member with fiber reinforced polymer (FRP) bars. Construction and Building Materials, 12, 453-462.

Turk, K., Benli, A., \& Calayir, Y. (2008). Bond strength of tension lap-splices in full scale self-consolidating concrete beams. Turkish Journal of Engineering and Environmental Sciences, 32, 377-386.

Valcuende, M., \& Parra, C. (2009). Bond behavior of reinforcement in self-compacting concrete. Journal of Construction and Building Materials, 23, 162-170. 